\title{
The serious business of listing authors
}

Sir - The recent leading article important contribution: the construction of the apparatus, on authorship (Nature 387, the Terabyte database software, the time-series analysis, the 831 ; 1997) struck a resonance detection efficiency determination, the comparison with within our team, as we have models or the actual drafting of the paper? How should we been wrestling with this demon compensate for the opportunity cost incurred by talented for many years. Ours is an scientists who took on essential but time-consuming code interdisciplinary undertaking, development, forgoing the chance to publish 'idea' papers? the success of which required extensive (and sometimes tedious) apparatus and software development before the first science results appeared (Nature 365, 621; 1993).

The joint effort of a team of computer scientists, astronomers and physicists was essential, and deciding who should appear as authors on what paper, and in what order, continues to be the source of much gut-wrenching internal debate.

Which was the more
After considerable debate, we decided early on to use alphabetical authorship, because it may be awful but it's better than the alternatives (most of which seem to involve hand-to-hand combat between alleged colleagues). We have not been able to devise a scheme that is 'fairer', despite considerable creative effort.

Having made the decision to go with the alphabetical approach, we nevertheless seem condemned to revisit the topic every other year. Legitimate issues such as career advancement for junior team members, recognition for individual effort and initiative, and significant cultural differences between our disciplines remain sources of debate.

I am convinced that, in large collaborative undertakings priority of individual contributions, the science is best served with alphabetical authorship. It is then incumbent on the more senior members of the team to spell out the individual

that by their very nature make it difficult to decide the relative e-mail: stubbs@radon.astro.washington.edu

contributions of students, postdocs and junior faculty members when recommendations are solicited, and to take active steps to draw attention to their efforts.

Concrete suggestions that might ease some of the problems include journal policies that would accommodate or even encourage papers authored by a team, with the individual aspects being secondary and less emphasis on first authorship for career advancement in disciplines where papers with 10 or more authors are not yet common.

\section{Christopher Stubbs}

Department of Physics,

Department of Astronomy,

Box 351580,

University of Washington,

Seattle, Washington, 98195, USA

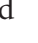

\section{Cloning, dignity and} \section{ethical revisionism}

Sir - Several texts published in Nature, notably a leading article devoted to the opinion of the French Consultative Ethics Committee (Nature 387, 321 \& 324; 1997) and John Harris's letter (Nature 387, 754; 1997), discuss the argument that application to man of asexual reproduction and cloning represents an affront to human dignity.

However, the two main arguments I set out in my Commentary (Nature 386, 119; 1997), and which were expanded in the French ethics committee opinion, were not accurately reported.

One of the components of human dignity is undoubtedly autonomy, the indeterminability of the individual with respect to external human will. No man or woman on Earth exists exactly as another has imagined, wished or created.

The birth of an infant by asexual reproduction would lead to a new category of people whose bodily form and genetic make-up would be exactly as decided by other humans. This would lead to the establishment of an entirely new type of relationship between the 'created' and the 'creator', which has obvious implications for human dignity.

Harris contests the validity of arguments based on the Kantian principle. But Kant did not say that respect for human dignity requires that an individual is never used as a means, but that an individual must never be used exclusively as a means. The word 'exclusively' makes all the difference between idle talk and one of the fundamental principles of modern bioethical thought.

The workman is indeed the means for doing work, the person who donates an organ is the means for saving the patient, but they are never exclusively a 'means', but also ends in themselves.

The creation of human embryos exclusively as a means, uniquely as a source of therapeutic material, would therefore seem in contradiction of Kant's principle, whose universality is far superior to that which Harris dismisses by omitting the word 'exclusively'.

In reality, the debate is about the status of the human embryo and its rights as a human individual, and the answers to this question differ greatly both between and within nations. In general, however, all those who would legitimize de novo creation of human embryos for research or preparation of therapeutic material base their position on their belief that the embryo is not a human individual, without calling Kant's principle into question.

Is Harris announcing the emergence of a revisionist tendency in bioethical thinking? Axel Kahn

Institut Cochin de Génétique Moléculaire,

24 Rue du Faubourg Saint-Jacques,

F-75014 Paris,

France

e-mail:kahn@icgm.cochin.inserm.fr

\section{Salmonella or Smithella?}

Sir - The history of science contains many examples of the subtitle of your recent leading article, "Authorship of a scientific paper is a privilege that is all too easily abused"'. The consequences can be farreaching for later honour and glory.

The salmonellae were named in 1900 undeservedly after the US veterinarian Daniel Elmer Salmon (1850-1914), director of the Bureau of Animal Industry of the US Department of Agriculture.

These pathogenic germs should in fairness be called smithellae, because their first member, called today Salmonella choleraesuis, was discovered by the greatest American pioneer of microbiology, Theobald Smith ${ }^{2,3}$ (1859-1934), who later (in 1893) also found the microbe that causes Texas cattle fever. But the first author of the paper "The bacterium of swineplague" " was Salmon, who had not taken part in the research at all and was only the superior of Smith, who was named as the second author. Unfortunately the designation Salmonella is so firmly rooted that it would be impossible to change it. Friedrich Katscher

Mariahilfer Str. 133,

A-1150 Vienna, Austria

\footnotetext{
1. Nature 387, 831 (1997).

2. Dolman, C. E., Theobald Smith, in Dictionary of Scientific Biography (Ed. Gillespie, C. C.) 12, 480-486 (Charles Scribner's Sons, New York, 1980).

3. Bibel, D. J. Milestones in Immunology, 31-32 (Springer, Berlin, 1988).

4. Amer. Monthly Microsc. J.7, 204-205 (1886).
} 